\title{
Prólogo del Libro de Embargo y Realización de Bienes de Luis Gonzalo Navarrete
}

\author{
Julio E. Salas Vivaldi \\ Profesor de Derecho Procesal \\ Facultad de Ciencias Jurídicas y Sociales \\ Universidad de Concepción
}

En un sistema económico en que las relaciones de ese carácter entre particulares y estos con instituciones financieras son cada vez más frecuentes y cuantiosas, surgen con mayor importancia los mecanismos judiciales llamados a obtener el cumplimiento forzado de las obligaciones contraidas por aquellos morosos de hacerlo, entre los que se cuenta el procedimiento ejecutivo que conduce al embargo de sus bienes y a la posterior reducción a dinero mediante la pertinente realización, haciéndose pago con su producto al acreedor.

Lo dicho demuestra desde ya la importancia del tema abordado en la otra parte a que el lector tiene en sus manos y la frecuencia de la utilización del embargo y realización de bienes en el medio económico y jurídico imperante justifica su estudio y divulgancia. Tales propósitos incentivaron, seguramente, a Luis Gonzalo Navarrete, cultor de Derecho Procesal, a abordar estas tareas, presentándose hoy el fruto de sus afanes. Lo hace a través de dos partes, destinadas cada uno al examen exhaustivo de las instituciones señaladas.

La primera comienza dando algunas consideraciones relativas a la responsabilidad patrimonial del deudor, su evolución en las diversas épocas y sistemas jurídicos y su actual concepción en el nuestro, resumida en el artículo 2465 del Código Civil como aquella que recae sobre todos los bienes del deudor, muebles o inmuebles presentes a futuros.

Precisado lo anterior, se entra de lleno al examen del embargo de tales bienes, esto es, su aprehensión por orden de juez competente ejecutada por ministro de fe, precisándose las fases o etapas que comprende y la selección de los mismos. Especial importancia se atribuye a la situación de los terceros que ven embargados bienes de su dominio para responder deudas ajenas y las actuaciones que deben llevar a efecto para liberarlos de tal medida, esto es las llamadas tercerías de dominio y posesión, de tan frecuente ocurrencia y no expedita tramitación.

La segunda parte de la obra la dedica el autor a la realización de los bienes embargados 0 , lo que es lo mismo, a la reducción a dinero de ellos, normalmente mediante su venta en público subasta, es decir, en remate, para que con su producto se haga pago al acreedor. Comienza estudiando su naturaleza jurídica y las diversas teorías que en el Derecho Comparado y en el nacional y la doctrina se han sustentado, inclinándose por aquella que lo concibe como un acto meramente procesal. Todo lo dicho sin descuidar el examen minucioso de la ley, la intensión de su autores la aplicación practicada por la jurisprudencia respecto de las diligencias que lo que lo 
configuran, incluyendo la situación de los demás acreedores, especialmente los hipotecarios y terceros en general.

En resumen, como el lector podrá comprobarlo, Gonzalo Navarrete da una visión amplia y completa de la situación actual relativa al embargo de bienes del deudor hasta la satisfacción de su deuda para con el acreedor mediante la reducción a dinero de los mismos a través de su realización por medio del pertinente remate. Para ello se apoya, a más de su aporte personal, en la jurisprudencia de nuestros tribunales y la opinión de la doctrina nacional y extranjera, especialmente la española, aprovechando, seguramente, sus estudios de post - grado.

Creo que basta lo dicho para demostrar que la obra motivo de estos comentarios constituirá un valioso aporte a jueces y abogados - sus principales destinatarios - en sus respectivos quehaceres sin perjuicio de su contribución a la formación del estudiante de Derecho y a la más expedita labor de Bancos, Instituciones Financieras y otras de igual naturaleza. 